\title{
Chemistry and Ecology
}

\section{Molecular changes of aquatic humic substances formed from four aquatic macrophytes decomposed under different oxygen conditions}

\author{
Argos Willian de Almeida Assunção, Brayan Pétrick de Souza, Wilson Tadeu \\ Lopes da Silva, Marcela Bianchessi Cunha-Santino \& Irineu Bianchini Jr.
}

To cite this article: Argos Willian de Almeida Assunção, Brayan Pétrick de Souza, Wilson Tadeu Lopes da Silva, Marcela Bianchessi Cunha-Santino \& Irineu Bianchini Jr. (2017) Molecular changes of aquatic humic substances formed from four aquatic macrophytes decomposed under different oxygen conditions, Chemistry and Ecology, 33:10, 918-931, DOI: 10.1080/02757540.2017.1393532

To link to this article: https://doi.org/10.1080/02757540.2017.1393532

曲 Published online: 26 Oct 2017.

Submit your article to this journal

III Article views: 27

Q View related articles $₫$

View Crossmark data $\nearrow$ 


\section{Molecular changes of aquatic humic substances formed from four aquatic macrophytes decomposed under different oxygen conditions}

Argos Willian de Almeida Assunção ${ }^{\mathrm{a} *}$, Brayan Pétrick de Souza ${ }^{\mathrm{a}}$, Wilson Tadeu Lopes da Silva ${ }^{b}$, Marcela Bianchessi Cunha-Santino ${ }^{\mathrm{a}, \mathrm{c}}$ and Irineu Bianchini Jr. ${ }^{\mathrm{a}, \mathrm{c}}$

aPrograma de Pós-Graduação em Ecologia e Recursos Naturais - PPGERN, Universidade Federal de São Carlos, São Carlos, Brazil; ${ }^{b}$ Empresa Brasileira de Pesquisa Agropecuária - Embrapa Instrumentação - CNPDIA, São Carlos, Brazil; 'Departamento de Hidrobiologia, Universidade Federal de São Carlos, São Carlos, Brazil

\begin{abstract}
Aquatic macrophytes' decomposition is a source of recalcitrant carbon in the long term contributing to humic substances (HS) formation. Understanding the influence of plant detritus quality and oxygen availability over molecular changes of these compounds provides ecological information related to their cycling. This study described the molecular variation of dissolved HS from Eichhornia azurea, Egeria najas, Oxycaryum cubense and Salvinia molesta decomposition under aerobic and anaerobic conditions. The aquatic HS formed from the four aquatic macrophytes showed similar features (e.g. molecular weight and aromaticity). This fact indicates little influence of the detritus quality or availability of oxygen on the fulvic acids (FA) and humic acid characteristics. Under aerobic condition a decrease in the polysaccharides content in FA occurred. HS from E. najas were related to less-recalcitrant features, while HS from S. molesta were related to recalcitrant.
\end{abstract}

\section{ARTICLE HISTORY}

Received 4 April 2017

Final Version Received 13

October 2017

\section{KEYWORDS}

E4/E6; dissolved organic carbon; dissolved oxygen; fulvic acid; FTIR; humic acid

\section{Introduction}

Dissolved organic carbon (DOC) consists of heterogeneous mixtures of carbon compounds from allochthonous and autochthonous sources constituting the major organic carbon pool in aquatic ecosystems [1]. Aquatic macrophytes can be responsible for up to $50 \%$ of the total input of carbon and nutrients in these environments, contributing to the maintenance of biogeochemical cycling of elements, especially in coastal regions [2,3].

In the early stages of aquatic macrophyte decomposition, the oxidation and dissolution of protoplasmic fractions and soluble compounds are the main factors responsible for mass loss [4]. The lignin and other components (i.e. structural compounds) are the major constituents of plant cellular walls [5] and are precursors of humic substances (HS) [6-8].

CONTACT Argos Willian de Almeida Assunção argos_willian@yahoo.com.br $\mathrm{E}$ Programa de Pós-Graduação em Ecologia e Recursos Naturais - PPGERN, Universidade Federal de São Carlos, Rodovia Washington Luís, km 235 - SP-310, São Carlos, SP CEP:13565-905, Brazil

*Present Address: Biology Department, University of São Paulo, Ribeirão Preto (SP), Brazil

(C) 2017 Informa UK Limited, trading as Taylor \& Francis Group 
HS are natural non-living organic substances that are ubiquitous in the environment formed by the humification process. Humification can be metabolically expressed as a prolonged stabilisation of organic substances with slow biodegradation [9]. One theory points out that humification occurs by supramolecular associations of heterogenic molecules, linked by weak bonds of big molecules [10].

Operationally, aquatic HS can be divided into two fractions: fulvic acids (FA) and humic acids (HA). The HA are characterised mainly by compounds from lignin degradation added to their structures during humification [11] and usually have an aromatic content and higher molecular weight compared to FA [11,12].

HS have important roles in aquatic environments. They affect the water transparency, they are assimilated by microbial metabolisms and are used as electron acceptors or donors during biogeochemical cycles [13-17]. Furthermore, HS can mobilise heavy metals by complexation and insecticides by absorption, they can be adsorbed on surfaces of many particles influencing dissolution and have acid-base properties with a wide range of pK values [18-20].

Concerning HS characteristics, we hypothesised that the source of organic matter (aquatic macrophyte species) and the environment condition (e.g. oxygen availability) act as determinant factors to configure the chemical properties of the dissolved HS. Identifying the molecular modification in $\mathrm{HS}$ is important information concerning their development and rearrangement over time during decomposition providing ecological information about the cycling of these compounds, which are usually refractory in aquatic environments. Therefore, this study aimed to describe the molecular variation of dissolved HS from Eichhornia azurea (Sw.) Kunth., Egeria najas Planch, Oxycaryum cubense (Poepp. and Kunth) and Salvinia molesta (Mitchell) decomposition under aerobic and anaerobic conditions.

\section{Methods}

\subsection{Sampling and handling}

Plants and water were collected from the Óleo Lagoon $\left(21^{\circ} 36^{\prime} \mathrm{S}\right.$ and $\left.47^{\circ} 49^{\prime} \mathrm{N}\right)$, an oxbow lake that belongs to the Mogi-Guaçu Ribver floodplain ( $400 \mathrm{~m}$ from the river) and is classified as oligotrophic and has little anthropogenic interference [21,22]. The weather in the region is classified as AW (Köppen) with rainy and dry seasons. The maximum depth of the Óleo Lagoon is $5.1 \mathrm{~m}$ and it has an area of $19,470 \mathrm{~m}^{2}$. The mean water temperature is $22.1^{\circ} \mathrm{C} \pm 1{ }^{\circ} \mathrm{C}$ and it has low concentrations of dissolved oxygen $\left(3.57 \pm 2.18 \mathrm{mg} \mathrm{L}^{-1}\right)$ and DOC (3.05 $\left.\pm 0.98 \mathrm{mg} \mathrm{L}^{-1}\right)$ [23].

Water samples were collected from the surface and bottom of the lagoon using Van Dorn samplers. The sampled water was filtered using cellulose acetate membrane ( $0.45 \mu \mathrm{m}$ pore). An aliquot of the water sample was reserved in natura to be used as an inoculum. This inoculum was mixed with the filtered water immediately before preparing the incubations ( $200 \mathrm{~mL}$ of inoculum per $20 \mathrm{~L}$ of filtered water). The adult specimens of $E$. azurea (rooted floating), E. najas (submersed), O. cubense (emergent) and S. molesta (floating) were chosen due to their abundance and dominance in Óleo Lagoon and their different ecological types that influences their tissue composition (i.e. content of recalcitrant compounds such as lignin). Collected plants were washed on site and in the laboratory. Subsequently, they were dried under $45^{\circ} \mathrm{C}$ until reaching a constant weight. The plants were cut into pieces of about $5 \mathrm{~cm}$. 


\subsection{Aquatic plants' incubations}

The incubations were performed in $1 \mathrm{~L}$ glass flasks containing $9 \mathrm{~g}$ of dried plant (detritus) for $900 \mathrm{~mL}$ of water (filtered + inoculum). The flasks were maintained in the dark at $22^{\circ} \mathrm{C}$. The anaerobic incubations were kept sealed and opened only on the respective sampling day, while the aerobic incubations were continuously aerated. On the sampling days (days $1,3,6,10,15,20,30,4560,90,120$ after the incubation preparation), the bottles were opened in triplicate. The particulate and dissolved fractions were separated by filtrations using cellulose acetate membrane $(0.45 \mu \mathrm{m}$ pore). From the dissolved fraction, the DOC and total dissolved nitrogen (TDN) (total organic carbon analyser - SHIMADZU TOC$\mathrm{LCSH} / \mathrm{CPH}$ ) were determined and a visible spectroscopy analysis was carried out to determine the E4/E6 ratios $(465 / 665 \mathrm{~nm})$. The carbon/nitrogen ratio $(\mathrm{C} / \mathrm{N})$ was calculated by dividing the DOC/12 per the TDN/14.

\subsection{HS acquisition and spectroscopy analysis}

Moreover, on sampling days 15, 30, 65, 90 and 120, HS were extracted using a column of DAX-8 resin [24]. After extraction, samples were acidified until $\mathrm{pH} \mathrm{1,} \mathrm{and} \mathrm{the} \mathrm{supernatant}$ (FA) was centrifuged and separated from the precipitate (HA) [25]. Consecutively, samples were dialysed (3500 Daltons - FISHER) and lyophilised. From the lyophilised samples, Fourier-transform infrared spectroscopy analysis from 400 to $4000 \mathrm{~cm}^{-1}$ was carried out (Perkin-Elmer/Spectrum 1000). Each spectrum obtained was the average of 32 readings (transmittance) for each sample, with a resolution of $4 \mathrm{~cm}^{-1}$. After freeze-drying, the samples were dissolved in $0.05 \mathrm{~N} \mathrm{NaHCO}_{3}$ solution [26] at concentrations of $1 \mathrm{mg} \mathrm{mL}^{-1}$, and then the wave scan of UV-visible spectrum (UV-VIS; from 200 to $800 \mathrm{~nm}$ ) analysis with a $1.0 \mathrm{~cm}$ quartz cuvette was performed. Deionised water was used as a blank and measurements were taken for every eight samples.

From the UV-VIS results, ratios of particular wavelengths were calculated in order to verify the DOC and HS characteristics:

- E4/E6 ratio $(465 / 665 \mathrm{~nm})$ - higher values of this ratio indicate lower molecular weight molecules, less aromaticity and less humification [26,27];

- E2/E4 ratio (270/407 $\mathrm{nm}$ ) - lower values indicate higher participation of porphyrin structures $(407 \mathrm{~nm}=$ Soret band), while higher values indicate participation of lignin-like structures [28].

The treatments were compared using analysis of variance repeated measures with $5 \%$ of significance.

\section{Results}

Higher $\mathrm{C} / \mathrm{N}$ values occurred in $E$. azurea aerobic incubations $(p<.01)$ and lower values in S. molesta anaerobic incubations $(p=.01)$. E. najas and $O$. cubense incubations showed similar $\mathrm{C} / \mathrm{N}$ values under both incubations ( $p=.12$ and $p=.76$, respectively). The dissolved fraction of $E$. azurea presented the highest $\mathrm{C} / \mathrm{N}$ values due to high $\mathrm{DOC}$ formation and low $\mathrm{N}$ concentrations. In the $E$. najas incubations, $\mathrm{C} / \mathrm{N}$ higher values occurred in the first 20-30 
days with a decreasing trend until the end of the incubation. Both $O$. cubense and S. molesta incubations showed low $\mathrm{C} / \mathrm{N}$ values with an increasing trend over time. Incubations with $S$. molesta presented the lowest dissolved carbon concentrations (Figure 1).

The dissolved fraction of all incubations showed an increase in molecular weight during the initial days of decomposition of plants detritus. E. azurea and O. cubense samples showed the highest molecular weight under aerobic conditions during the whole incubation period $(p<.01$ and $p=.02$, respectively), while for $E$. najas and $S$. molesta samples, both conditions presented similar values $(p=.61$ and $p=.83$, respectively). However, anaerobic incubations had higher E4/E6 ratio values in early incubation and lower values in the final days (Figure 2).

E4/E6 ratio of dissolved HS samples were higher than E4/E6 ratios of DOC. Little variation occurred during incubations and generally oxygen availability did not interfere
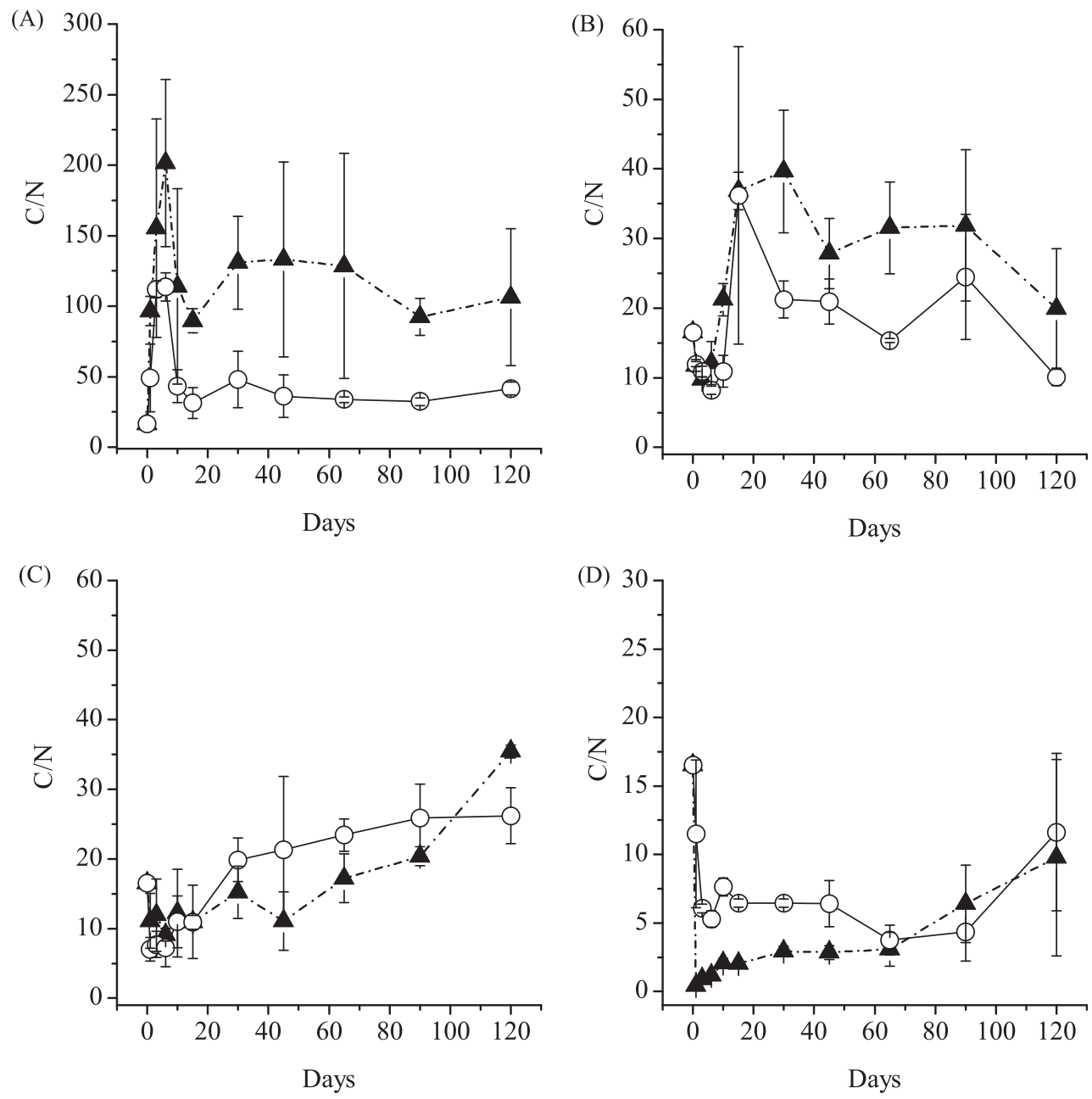

Figure 1. The dissolved organic carbon/total dissolved nitrogen $(C / N)$ ratios of the leachate formed during aquatic macrophytes decomposition under aerobic (white circle) and anaerobic (black triangle) conditions ( $\mathrm{A}=$ Eichhornia azurea; $\mathrm{B}=$ Egeria najas; $\mathrm{C}=$ Oxycaryum cubense; $\mathrm{D}=$ Salvinia molesta). 

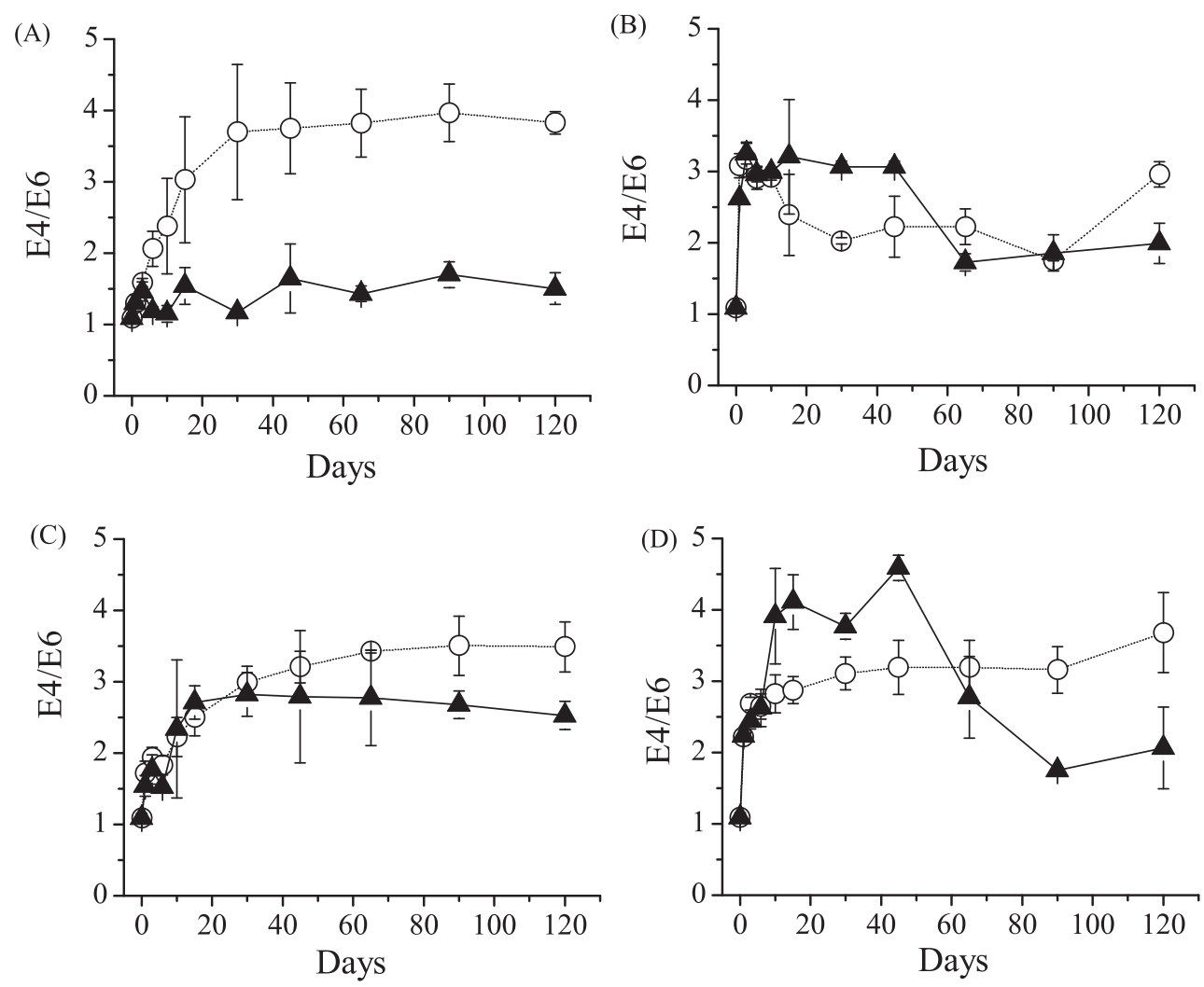

Figure 2. The E4/E6 ( $465 / 665 \mathrm{~nm})$ ratios of the dissolved fraction formed during aquatic macrophytes decomposition under aerobic (white circle) and anaerobic (black triangle) conditions ( $\mathrm{A}=$ Eichhornia azurea; $\mathrm{B}=$ Egeria najas; $\mathrm{C}=$ Oxycaryum cubense; $\mathrm{D}=$ Salvinia molesta).

with molecular weight, except for FA formed from E. azurea $(p=.03)$ and FA and HA formed from Oxycaryum cubense ( $p=.01$ and $p<.01$, respectively).

During the incubation period, all samples showed few variations of E2/E4 ratios (Table 1). There were no differences among treatments for all species, except for HA formed during $E$. najas and $O$. cubense incubations ( $p=.04$ and $p=.03$, respectively). This indicates that the content of lignin-like products in humic compounds was not affected by decomposition under aerobic or anaerobic conditions.

Generally, the intensity of bands occurred in similar regions for all the samples: $\sim 3300 \mathrm{~cm}^{-1}$ - related to $\mathrm{N}-\mathrm{H}$ or $\mathrm{O}-\mathrm{H}$ stretching of phenols, alcohols, carboxylic acids

Table 1. Averages and standard deviations (SD) of E2/E4 ratios (207/407 nm) of aquatic humic compounds formed from aquatic macrophyte decomposition under aerobic and anaerobic conditions.

\begin{tabular}{|c|c|c|c|c|c|c|c|c|}
\hline & \multicolumn{4}{|c|}{ Fulvic } & \multicolumn{4}{|c|}{ Humic } \\
\hline & \multicolumn{2}{|c|}{ Aerobic } & \multicolumn{2}{|c|}{ Anaerobic } & \multicolumn{2}{|c|}{ Aerobic } & \multicolumn{2}{|c|}{ Anaerobic } \\
\hline & Average & SD & Average & SD & Average & SD & Average & SD \\
\hline E. azurea & 4.86 & 0.14 & 4.59 & 0.30 & 4.25 & 0.20 & 4.20 & 0.34 \\
\hline E. najas & 5.06 & 0.39 & 5.10 & 0.22 & 4.38 & 0.37 & 4.69 & 0.39 \\
\hline O. cubense & 5.20 & 0.34 & 5.40 & 0.30 & 4.84 & 0.15 & 4.67 & 0.18 \\
\hline S. molesta & 5.19 & 0.14 & 6.24 & 1.01 & 4.47 & 0.18 & 5.39 & 0.94 \\
\hline
\end{tabular}


and/or other substances which contain hydroxyl groups; $2900 \mathrm{~cm}^{-1}$ - related to aliphatic $(\mathrm{C}-\mathrm{H})_{n}$ stretches, such as fatty acids and waxes; $\sim 1720 \mathrm{~cm}^{-1}$ - related to $\mathrm{C}=\mathrm{O}$ stretches of $\mathrm{COOH}$, aldehydes and ketones; $\sim 1620 \mathrm{~cm}^{-1}$ aromatic $\mathrm{C}=\mathrm{C}$ vibration, carbon-carbon bonds, symmetric stretching of $\mathrm{COO}^{-}$groups, and $\mathrm{H}$-bonded $\mathrm{C}=\mathrm{O}$ of conjugated ketones; $\sim 1400$ $\mathrm{cm}^{-1}$ - related to $\mathrm{O}-\mathrm{H}$ deformation and $\mathrm{C}-\mathrm{O}$ stretching of phenolic $\mathrm{OH}$; and $\sim 1050 \mathrm{~cm}^{-1}$ related to $\mathrm{C}-\mathrm{O}$ stretching of polysaccharides or derivatives [29-33] (Figures 4 and 5).

Dissolved FA formed during $E$. azurea degradation had a similar infrared response under aerobic and anaerobic conditions. However, under aerobic conditions, the band related to polysaccharides $\left(\sim 1050 \mathrm{~cm}^{-1}\right)$ showed lower intensity over time, indicating

Fulvic acids

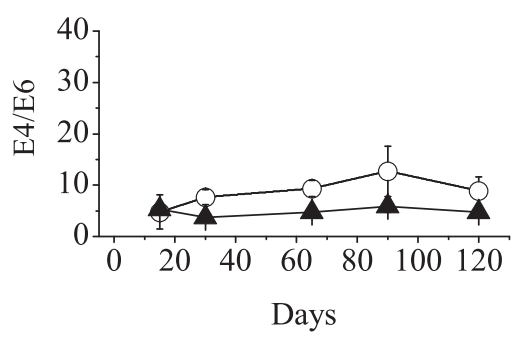

E. najas

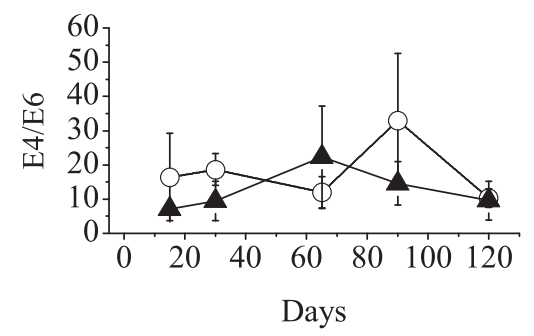

O. cubense

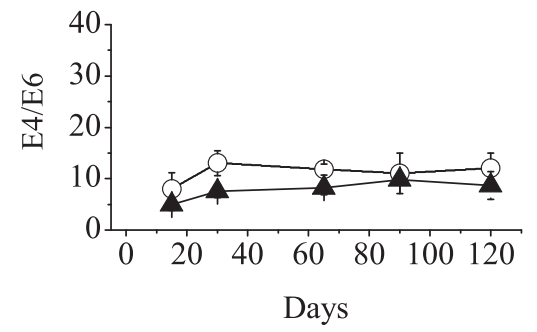

S. molesta

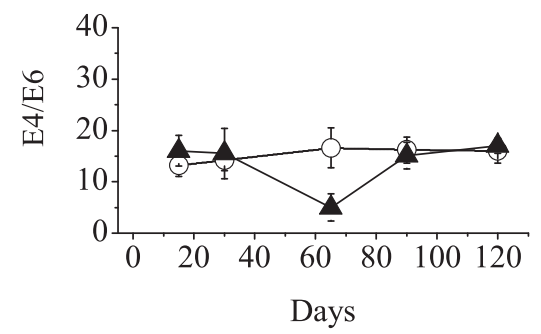

Humic acids
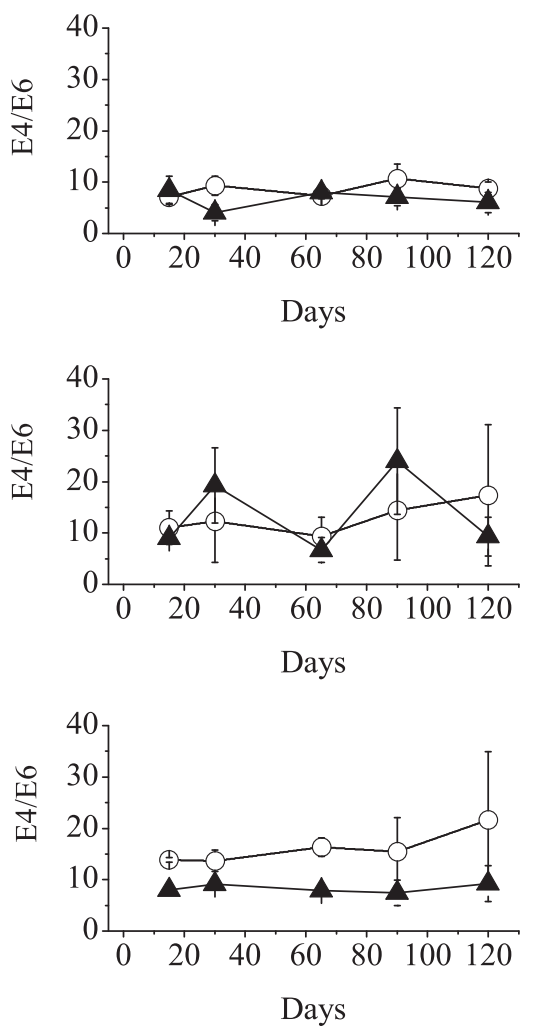

40

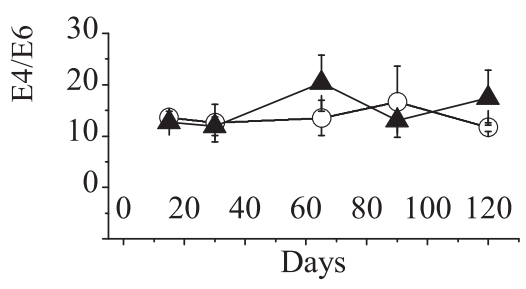

Figure 3. E4/E6 ratios ( $465 / 665 \mathrm{~nm}$ ) of dissolved humic substances formed from aquatic macrophyte decomposition under aerobic (white circle) and anaerobic (black triangle) conditions. 
Aerobic

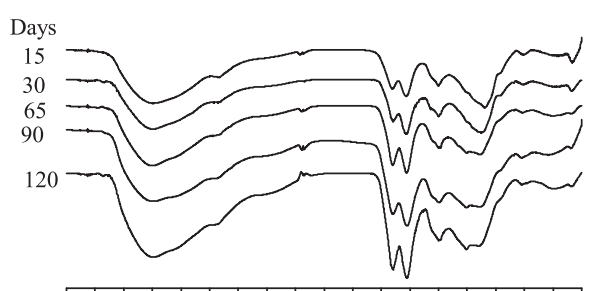

$\begin{array}{llllllllll}4000 & 3600 & 3200 & 2800 & 2400 & 2000 & 1600 & 1200 & 800 & 400\end{array}$ $\mathrm{cm}^{-1}$

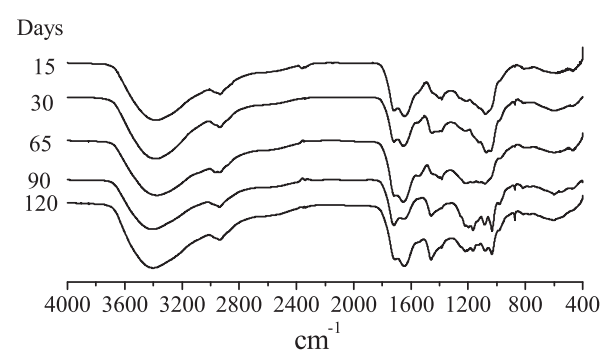

Days

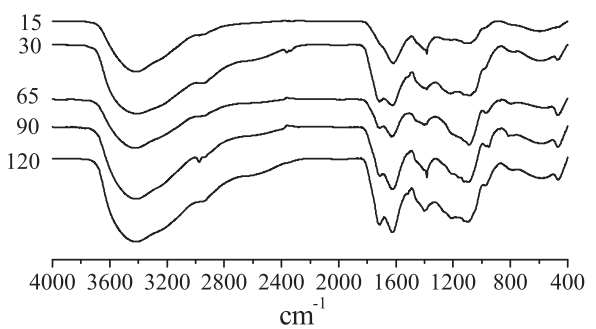

Days

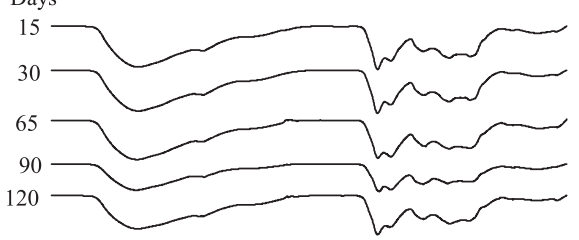

$\begin{array}{llllllllllllll}4000 & 3600 & 3200 & 2800 & 2400 & 2000 & 1600 & 1200 & 800 & 400\end{array}$ $\mathrm{cm}^{-1}$
Anaerobic

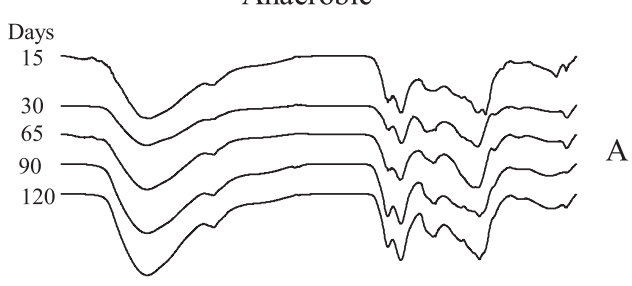

$\begin{array}{llllllllll}4000 & 3600 & 3200 & 2800 & 2400 & 2000 & 1600 & 1200 & 800 & 400\end{array}$ $\mathrm{cm}^{-1}$
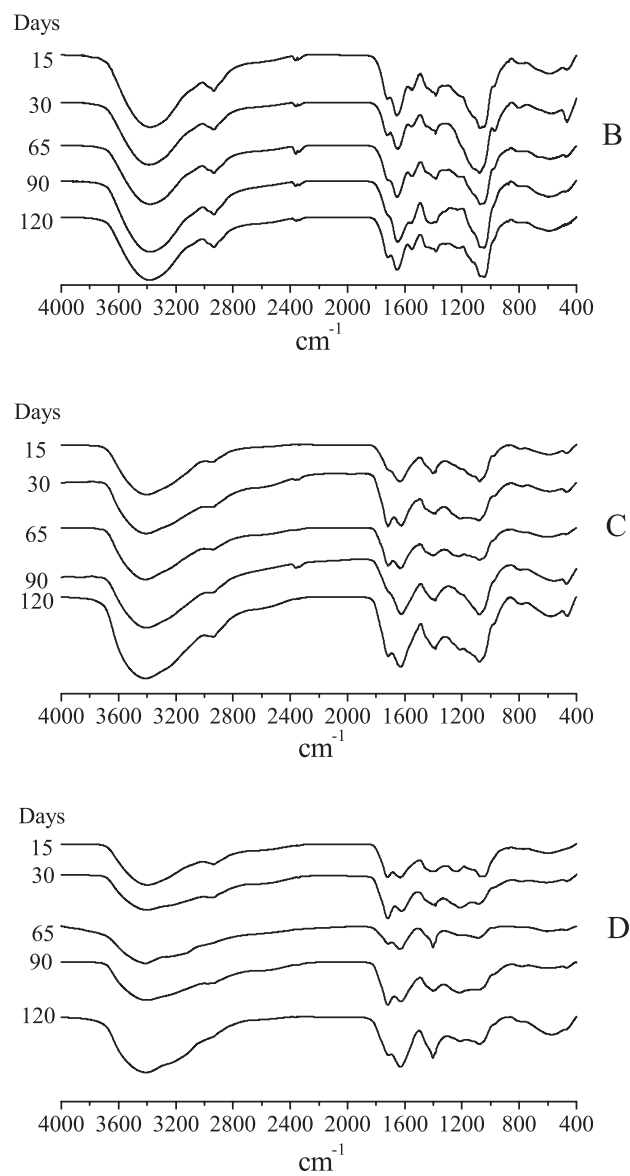

Figure 4. The infrared spectroscopy (FTIR) of aquatic fulvic acid formed during aquatic macrophyte decomposition under aerobic and anaerobic conditions $(\mathrm{A}=$ Eichhornia azurea; $\mathrm{B}=$ Egeria najas; $\mathrm{C}=$ Oxycaryum cubense; $\mathrm{D}=$ Salvinia molesta).

processing of this molecular group. In addition, under anaerobic conditions, the band related to $\mathrm{N}-\mathrm{H}\left(\sim 1400 \mathrm{~cm}^{-1}\right)$ became more intense over time and similar to aerobic FA in the last days of incubation (Figure 4).

The dissolved FA formed during E. najas degradation had similar characteristics to E. azurea. The $\sim 1050 \mathrm{~cm}^{-1}$ region also became less intense over time under aerobic 
Aerobic

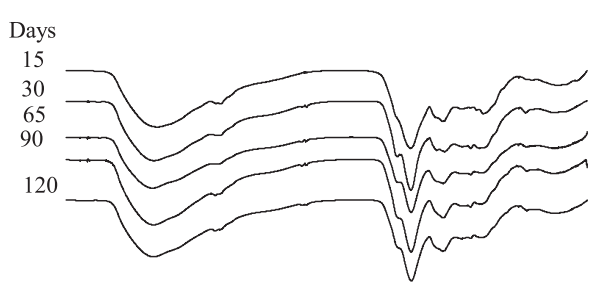

$\begin{array}{llllllllllll}4000 & 3600 & 3200 & 2800 & 2400 & 2000 & 1600 & 1200 & 800 & 400\end{array}$ $\mathrm{cm}^{-1}$

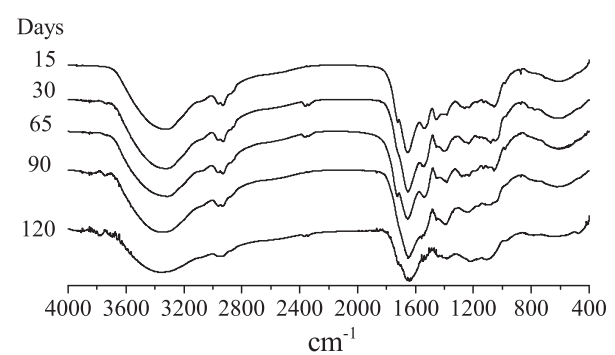

Days

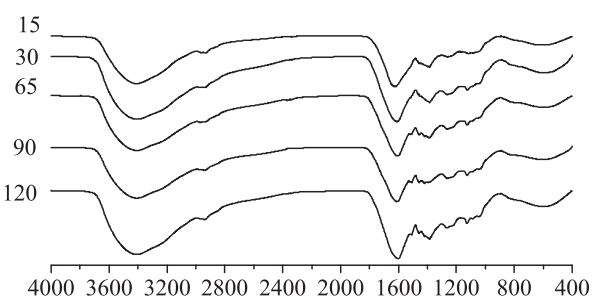
$\mathrm{cm}^{-1}$

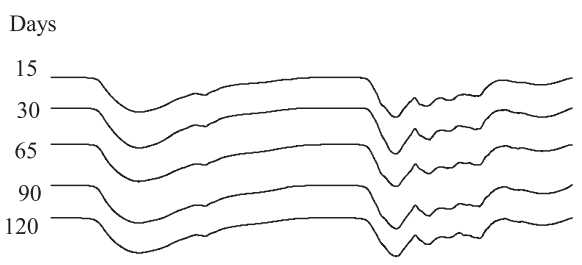

$\begin{array}{lllllllllllll}4000 & 3600 & 3200 & 2800 & 2400 & 2000 & 1600 & 1200 & 800 & 400\end{array}$ $\mathrm{cm}^{-1}$
Anaerobic

Days

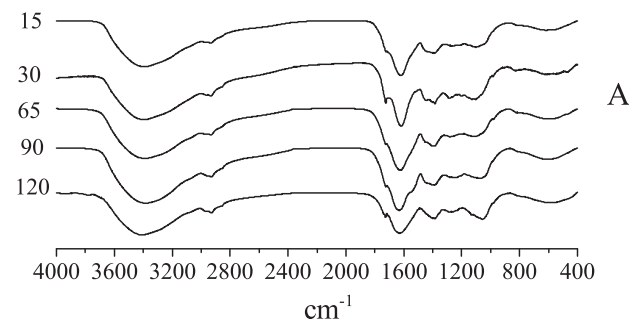

Days

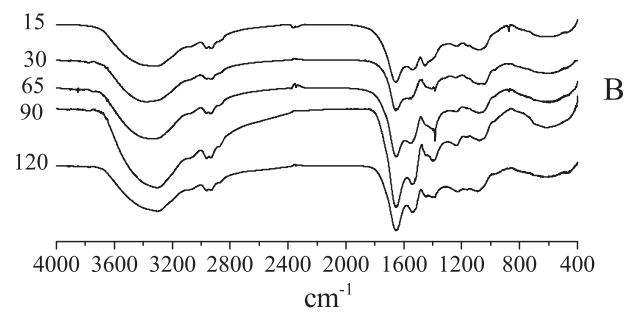

Days

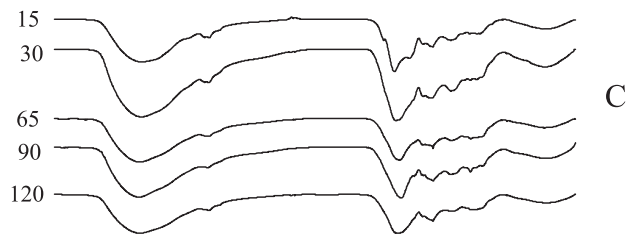

$\begin{array}{llllllllll}4000 & 3600 & 3200 & 2800 & 2400 & 2000 & 1600 & 1200 & 800 & 400\end{array}$ $\mathrm{cm}^{-1}$

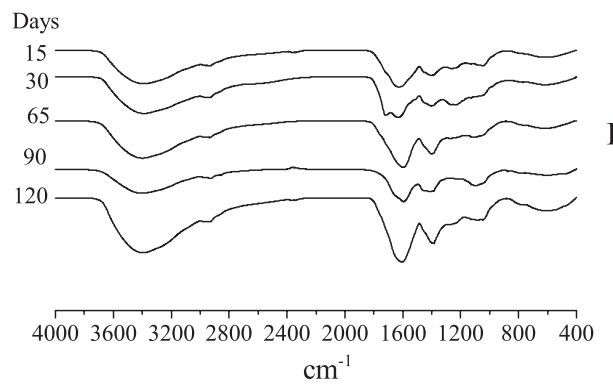

Figure 5. The infrared spectroscopy (FTIR) of aquatic humic acid formed during aquatic macrophyte decomposition under aerobic and anaerobic conditions $(\mathrm{A}=$ Eichhornia azurea; $\mathrm{B}=$ Egeria najas; $\mathrm{C}=$ Oxycaryum cubense; $\mathrm{D}=$ Salvinia molesta).

conditions. The main differences are a more intense band at $\sim 2900 \mathrm{~cm}^{-1}$, indicating more aliphatic content and less recalcitrance, and a lower intensity at $\sim 1720 \mathrm{~cm}^{-1}$, indicating less formation of ketones and aldehydes due to polysaccharides degradation (Figure 4). 
The FA formed during $O$. cubense degradation showed low intensity in the $\sim 2900 \mathrm{~cm}^{-1}$ region showing a low presence of aliphatic structures. The E. najas samples showed less intensity for the $\sim 1720 \mathrm{~cm}^{-1}$ band. However, the main difference was observed in the $\sim 1050 \mathrm{~cm}^{-1}$ region, where an increase in intensity over time occurred indicating an increase in the polysaccharide content and humification process. In this region, the aerobic conditions favoured a spread peak even when the intensity increased. The dissolved FA formed during S. molesta decomposition showed the lowest intensity in all infrared regions. The low intensity in $\sim 3300$ and $\sim 2900 \mathrm{~cm}^{-}$ ${ }^{1}$ regions may indicate that the FA from $S$. molesta has more aromatic features than other plants. In addition, the low intensity of the $\sim 1050 \mathrm{~cm}^{-1}$ region indicates less polysaccharide content (Figure 4).

The dissolved HA formed from macrophyte decomposition showed similar peak regions to dissolved FA samples. The clearest difference was a decrease in the intensity of the $\sim 1050 \mathrm{~cm}^{-1}$ peak in $\mathrm{HA}$, indicating a lower presence of $\mathrm{C}-\mathrm{O}$ stretches of polysaccharides or derivatives and an advanced stage in the humification process (Figure 5).

Dissolved HA formed from aerobic $E$. azurea degradation did not change over time. The only evidence of intensity modification is an increase around the $\sim 1400 \mathrm{~cm}^{-1}$ region, showing an increase in carboxylate. However, the HA formed under anaerobic conditions showed an increase in intensity around the $\sim 2900, \sim 1400$ and $\sim 1050 \mathrm{~cm}^{-1}$ regions. This fact shows evidence of a decrease in humification and an increase in polysaccharide content. These bands had higher intensities under anaerobic treatments compared to aerobic treatments (Figure 5).

The dissolved HA formed from $E$. najas decomposition had the highest intensity in the $\sim 2900 \mathrm{~cm}^{-1}$ region compared to the others species, showing that this compound has high aliphatic content and is less recalcitrant. Under aerobic conditions, it can be observed that there was an increase in intensity around the $\sim 1400 \mathrm{~cm}^{-1}$ region, while under anaerobic conditions an increase around the $\sim 1525 \mathrm{~cm}^{-1}$ region showed the presence of aromatic $C$ $=\mathrm{C}$ and $/$ or amides $\mathrm{C}=\mathrm{N}$ (Figure 5).

Dissolved HA formed from $O$. cubense decomposition presented bands in similar regions to $E$. azurea and $E$. najas. However, the region from around $\sim 1525$ to $\sim 800 \mathrm{~cm}^{-1}$ showed undefined peaks with low intensity, indicating high humification and low proportions of polysaccharides and derivatives. HA formed under aerobic and anaerobic conditions had similar band regions. For dissolved HA formed in the S. molesta decomposition, the lowest intensity occurred around the $\sim 3000 \mathrm{~cm}^{-1}$ region compared with other species. This showed high aromaticity of HA compounds. It can also be observed that there was a peak around the $\sim 1400 \mathrm{~cm}^{-1}$ region and a low-intensity band around the $\sim 1050 \mathrm{~cm}^{-1}$ region, indicating a high carboxylate formation and a low content of polysaccharides and derivatives (Figure 5).

\section{Discussion}

In general, dissolved HS formed from leachates of four aquatic macrophyte species showed similar features of each other (e.g. high molecular weight, same functional groups) [34]. Different methods to characterise molecular features of HS were important to evaluate qualitative changes resulting due to macrophyte species or oxygen availability [35]. 
In a previous study [36], it became clear that O. cubense and S. molesta detritus are more recalcitrant than $E$. azurea and $E$. najas detritus. These recalcitrant detritus generated less DOC and promoted higher contents of dissolved HS, mainly under aerobic conditions. Besides, dissolved humic compounds represented a small fraction of the total detritus of each plant. However, due to their recalcitrance, the dissolved HS can accumulate in aquatic environments [36].

Although availability of oxygen increases detritus mineralisation and generates higher amounts of $\mathrm{HA}$, the presence or absence of oxygen did not seem to be a determinant factor for the features of the dissolved organic carbon, including the HS yields.

$\mathrm{C} / \mathrm{N}$ ratio did not show a pattern according to oxygen availability, but this variable is an indicator of the detritus quality. E. azurea and E. najas dissolved fraction showed higher values of $\mathrm{C} / \mathrm{N}$ compared to $O$. cubense and S. molesta (Figure 1). This was an expected result since $E$. azurea and $E$. najas have higher contents of the labile/soluble fraction [36]. Besides that emergent macrophytes (e.g. O. cubense) usually present a lower $\mathrm{C} / \mathrm{N}$ content than floating and submerged macrophytes (e.g. E. najas) (submerged $=21.2-$ 30.5; emergent $=13.0-22.4$; [31]).

Under anaerobic conditions, mineralisation promotes an accumulation of intermediate compounds, since fermentative processes partially degrade organic molecules [37]. Furthermore, anaerobic bacteria has limitations to hydrolyse complex molecules and aromatic compounds [38]. These facts agree with E4/E6 ratios of DOC, where low values under anaerobic conditions occurred indicating higher molecular weight in this condition (Figure 2).

Although, generally E4/E6 and E2/E4 ratios of FA and HA showed similar patterns under both conditions (Figure 3 and Table 1), FA from E. najas and FA and HA from O. cubense incubated in anaerobic conditions favoured higher molecular weight. HS can present a decrease in E4/E6 and E2/E4 ratios indicating changes in composition and/or content of high weight and lignin-like molecules [28,39]. However, our results indicate that the molecular weight and lignin-like content in dissolved HA and FA compositions experience a low influence of aquatic macrophyte species (i.e. detritus composition). In addition, these HS presented few changes in these characteristics during aerobic and anaerobic degradation.

The main molecular groups presented in FA and HA were similar regardless of the detritus source and oxygen availability (Figures 4 and 5) [34]. The main variation observed in the FA samples was the decrease in polysaccharides molecules, mainly under aerobic conditions [33]. The decrease in intensity of the bands related to polysaccharide content indicates that FA were being processed. As polysaccharides are compounds with the relevant energetic content, the metabolisation of these compounds is expected $[27,40]$.

Dissolved FA derived from $E$. najas showed closer relation to higher aliphatic content while the opposite was observed for S. molesta (Figure 4). Moreover, FA derived from E. najas was the only FA sample where an increase in the phenolic $\mathrm{O}-\mathrm{H}$ content was not observed $\left(\sim 1400 \mathrm{~cm}^{-1}\right)$. This agrees with the fact that $E$. najas has more labile content and presents higher mass decay than the other studied species [36]. However, this fact seems to not influence FA mass loss [36].

In general, HA samples from different species detritus had similar features (Figure 5). An increase in the polysaccharide content occurred in $\mathrm{HA}$ from E. azurea. This could be related to cellulose degradation [40]. Moreover, HA from E. azurea presented higher mass decay 
than other plants [36]. The HA from E. najas were also related to more aliphatic content, but under aerobic conditions a decrease in the aliphatic content was observed (Figure 5). This might be related to lower cell wall fraction and lignin content than the other plants [41-45].

Generally, aromaticity in the macrophyte-derived DOM is lower than that in DOM from the allochthonous sources, sediment or the HS, but similar to or higher than that in the phytoplankton derived from DOM [31].

Although some studies show higher decays of HA than FA $[36,39,46]$, the spectroscopy analysis demonstrated that $\mathrm{HA}$ are more resistant to molecular changes than FA, once less qualitative variations were noticed in the HA samples (Figures 4 and 5).

\section{Conclusions}

Based on adopted experiments, it can be concluded that aquatic HS formed from four aquatic macrophytes leachates presented similar features. This shows little influence of the detritus quality or availability of oxygen on the FA and HA characteristics. Anaerobic condition resulted mainly in a DOC with a higher molecular weight. Aerobic condition favoured a decrease in polysaccharides content of FA from all plants. FA and HA derived from $E$. najas were related to less-recalcitrant features and higher aliphatic molecule content. FA and HA from S. molesta were related to recalcitrant structures and presented low chemical change than HS from other plants.

\section{Disclosure statement}

No potential conflict of interest was reported by the authors.

\section{Funding}

We thank Fundação de Amparo à Pesquisa do Estado de São Paulo - FAPESP for the financial support [grant numbers 11/16990-4, 11/10178-6].

\section{Notes on Contributors}

Argos Willian de Almeida Assunção holds a bachelor's degree in Biological Sciences from the Faculty of Agrarian and Veterinary Sciences (UNESP), Jaboticabal, SP (2007), a master's degree in Aquaculture from the UNESP Aquaculture Center (2011) and a Ph.D. in Ecology and Natural Resources from the Federal University of São Carlos (2015). He is currently a temporary Professor at the University of São Paulo. He has experience in the field of Ecology, with emphasis in Ecology of Ecosystems. He acts mainly on the following subjects: Humic substances, Aquatic Macrophytes, Limnology.

Brayan Pétrick de Souza holds a bachelor's degree in Biological Sciences from the Passos Higher Education Foundation (2012) and a Master's degree in Ecology and Natural Resources from the Federal University of São Carlos - UFSCar (2015), working mainly on the following themes: general limnology, general ecology, carbon cycle in aquatic ecosystems and humic substances derived from aquatic plants.

Wilson Tadeu Lopes da Silva holds a bachelor's degree in Chemistry from the University of São Paulo (1991), a Masters in Chemistry (Analytical Chemistry) from the University of São Paulo (1995) and a Ph.D. in Chemistry (Analytical Chemistry) from the University of São Paulo (2000). He 
is currently Researcher at Embrapa Instrumentation, and has experience in Chemistry, with emphasis in Analytical Chemistry and Environmental Chemistry. He works mainly in the following subjects: organic matter of the soil, humic acids, humic substances, use and evaluation of the impact of the use of residues in agriculture with emphasis on organic matter, anaerobic biodigestors, rural basic sanitation, spectroscopic methods of analysis and electroanalysis applied to problems with environmental impacts. He is an effective member of the International Society of Humic Substances (IHSS). $\mathrm{He}$ is currently an accredited advisor in the postgraduate program in Chemistry of the Institute of Chemistry of São Carlos, University of São Paulo. In March 2015, he assumed the position of Deputy Chief of Research and Development of Embrapa Instrumentation.

Marcela Bianchessi Cunha-Santino holds a bachelor's degree in Biological Sciences from the Federal University of São Carlos (1996), a Master's degree in Ecology and Natural Resources from the Federal University of São Carlos (1999) and a doctorate in Ecology and Natural Resources from the Federal University of São Carlos (2003). The author is currently Associate Professor I of the Hydrobiology Department of the Federal University of São Carlos. She has experience in Applied Ecology, with emphasis on Applied Limnology, acting mainly on the following subjects: aquatic macrophytes, decomposition, mathematical models, enzymatic activity, primary production, bioassays and limnological inventory.

Irineu Bianchini Jr. holds a bachelor's degree in biological sciences from the Federal University of São Carlos (1980), a bachelor's degree in biological sciences from the Federal University of São Carlos (1978), a master's degree in ecology and natural resources from the Federal University of São Carlos (1982) in Ecology and Natural Resources by the Federal University of São Carlos (1985) and post-doctorate by the Federal University of São Carlos (1986). He is currently a full professor at the Federal University of São Carlos, and has experience in the field of Ecology, with emphasis in Applied Ecology. He acts mainly on the following topics: aquatic macrophytes, humic substances, Carbon Cycle, aquatic ecosystems, organic matter and debris.

\section{References}

[1] Cole JJ, Prairie YT, Caraco NF, et al. Plumbing the global carbon cycle: integrating inland waters into the terrestrial carbon budget. Ecosystems. 2007;10:172-185.

[2] Benner R, Moran MA, Hodson RE. Biogeochemical cycling of lignocellulosic carbon in marine and freshwater ecosystems: relative contributions of procaryotes and eucaryotes. Limnol Oceanogr. 1986;31:89-100.

[3] Wurzbacher C, Bärlocher F, Grossart H. Fungi in lake ecosystems. Aquat Microb Ecol. 2010;59:125-149.

[4] Bianchini I, Jr., Cunha-santino MB. Model parameterization for aerobic decomposition of plant resources drowned during man-made lakes formation. Ecol Modell. 2011;222:1263-1271.

[5] Pérez J, Muñoz-Dorado J, De La Rubia T, et al. Biodegradation and biological treatments of cellulose, hemicellulose and lignin: An overview. Int Microbiol. 2002;5:53-63.

[6] Thurman EM. Organic geochemistry of natural waters. Dordrecht: Springer Netherlands; 1985.

[7] Stevenson FJ. Humus chemistry: genesis, composition, reactions. 2nd ed. New York (NY): Wiley. J Chem Educ.; 1995.

[8] Bikovens O, Telysheva G, liyama K. Comparative studies of grass compost lignin and the lignin component of compost humic substances. Chem Ecol. 2010;26:67-75.

[9] Kögel-Knabner I. The macromolecular organic composition of plant and microbial residues as inputs to soil organic matter. Soil Biol Biochem. 2002;34:139-162.

[10] Piccolo A, Cozzolino A, Conte P, et al. Polymerization of humic substances by an enzyme-catalyzed oxidative coupling. Naturwissenschaften 2000;87:391-394.

[11] Azevedo Jd, Nozaki J. Análise de fluorescência de substâncias húmicas extraídas da água, solo e sedimento da Lagoa dos Patos - MS. Quim Nova. 2008;31:1324-1329.

[12] Peña-méndez ME, Havel J, Patočka J. Humic substances - compounds of still unknown structure: applications in agriculture, industry, environment, and biomedicine. J Appl Biomed. 2005;3:13-24. 
[13] Kalantary RR, Badkoubi A. Effect of humic compounds on bacterial growth in bioremediation of pahs. Iranian J Environ Health Sci Eng. 2006;3:31-38.

[14] Klüpfel L, Piepenbrock A, Kappler A, et al. Humic substances as fully regenerable electron acceptors in recurrently anoxic environments. Nat Geosci. 2014;7:195-200.

[15] Köhler SJ, Kothawala D, Futter MN, et al. In-lake processes offset increased terrestrial inputs of dissolved organic carbon and color to lakes. PLoS One. 2013;8:e70598.

[16] Rodríguez $P$, Byström $P$, Geibrink E, et al. Do warming and humic river runoff alter the metabolic balance of lake ecosystems? Aquat Sci. 2016;78:717-725.

[17] Yang C-M, Wang M-C, Lu Y-F, et al. Humic substances affect the activity of chlorophyllase. J Chem Ecol. 2004;30:1057-1065.

[18] Misra V, Pandey SD, Viswanathan PN. Environmental significance of humic acid in the sequestration of metals. Chem Ecol. 1996;13:103-112.

[19] Pandey AK, Pandey SD, Misra V, et al. Formation of soluble complexes of metals with humic acid and Its environmental significance. Chem Ecol. 1999;16:269-282.

[20] Uyguner CS, Bekbolet M. A comparative study on the photocatalytic degradation of humic substances of various origins. Desalination. 2005;176:167-176.

[21] Rocha O, Espindola ELG, Rietzler AC, et al. Diversidade do zooplâncton nas lagoas marginais do rio Mogi-Guaçu: III. Copepoda (Crustacea). In: Santos JE, Pires JSR, editors. Estud. Integr. em ecossistemas - Estação Ecológica Jataí. 2nd ed. São Carlos: RiMa; 2000. p. 587-598.

[22] Wisniewski MJS, Rocha O, Rietzler AC. Diversidade do zooplõncton nas lagoas marginais do rio Mogi-Guacu: II Cladocera (Crustacea, Branchiopoda). In: Santos JE, Pires JSR, editors. Estud. Integr. em ecossistemas - Estação Ecológica Jataí. 2nd ed. São Carlos: RiMa; 2000. p. 559-586.

[23] Sciessere L. Ação das enzimas extracelulares na dinâmica da decomposição de macrófitas aquáticas [dissertation]. São Carlos (SP): Universidade Federal de São Carlos; 2011.

[24] Thurman EM, Malcolm RL. Preparative isolation of aquatic humic substances. Environ Sci Technol. 1981;15:463-466.

[25] Steinberg CEW. Ecology of humic substances in freshwaters. Berlin: Springer Berlin Heidelberg; 2003.

[26] Chen Y, Senesi N, Schnitzer M. Information provided on humic substances by E4/E6 ratios. Soil Sci Soc Am J. 41:1977: 352.

[27] Fialho LL, Silva Wd, Milori DMBP, et al. Characterization of organic matter from composting of different residues by physicochemical and spectroscopic methods. Bioresour Technol. 2010;101:1927-1934.

[28] Budziak CR, Maia CMBF, Mangrich AS. Transformações químicas da matéria orgânica durante a compostagem de resíduos da indústria madeireira. Quim Nova. 2004. p. 399-403.

[29] Senesi N, D'Orazio V, Ricca G. Humic acids in the first generation of EUROSOILS. Geoderma. 2003;116:325-344.

[30] Francioso O, Sanchez-Cortes S, Tugnoli V, et al. Infrared, Raman, and nuclear magnetic resonance $(1 \mathrm{H}, 13 \mathrm{C}$, and $31 \mathrm{P})$ spectroscopy in the study of fractions of peat humic acids. Appl Spectrosc. 1996;50:1165-1174.

[31] Qu X, Xie L, Lin Y, et al. Quantitative and qualitative characteristics of dissolved organic matter from eight dominant aquatic macrophytes in Lake Dianchi, China. Environ Sci Pollut Res Int. 2013;20:7413-7423.

[32] Oliveira JL, Boroski M, Azevedo JCR, et al. Spectroscopic investigation of humic substances in a tropical lake during a complete hydrological cycle. Acta Hydrochim Hydrobiol. 2006;34:608617.

[33] He X, Xi B, Wei Z, et al. Spectroscopic characterization of water extractable organic matter during composting of municipal solid waste. Chemosphere 2011;82:541-548.

[34] Sánchez-Monedero MA, Cegarra J, García D, et al. Chemical and structural evolution of humic acids during organic waste composting. Biodegradation 2002;13:361-371.

[35] Abbt-Braun G, Lankes U, Frimmel FH. Structural characterization of aquatic humic substances ? The need for a multiple method approach. Aquat Sci. 2004;66:151-170. 
[36] Assunção AWA, Souza BP, Cunha-Santino MB, et al. Formation and mineralization kinetics of dissolved humic substances from aquatic macrophytes decomposition. J. Soils Sediments. 2016;1-13. DOI:10.1007/s11368-016-1519-x

[37] Bianchini I, Jr, Cunha-Santino Md, Ribeiro J, et al. Implication of anaerobic and aerobic decomposition of Eichhornia azurea (Sw.) Kunth. on the carbon cycling in a subtropical reservoir. Brazilian J Biol. 2014;74:100-110.

[38] Kristensen E, Ahmed SI, Devol AH. Aerobic and anaerobic decomposition of organic matter in marine sediment: which is fastest? Limnol Oceanogr. 1995;40:1430-1437.

[39] Grinhut T, Hadar Y, Chen Y. Degradation and transformation of humic substances by saprotrophic fungi: processes and mechanisms. Fungal Biol Rev. 2007;21:179-189.

[40] Chen H-L, Zhou J-M, Xiao B-H. Characterization of dissolved organic matter derived from rice straw at different stages of decay. J Soils Sediments. 2010;10:915-922.

[41] Gimenes KZ, Cunha-Santino Md, Bianchini I. Cellulase activity in anaerobic degradation of aquatic macrophytes tissues. Fundam Appl Limnol. 2013;183:27-39.

[42] Sciessere L, Cunha-Santino MB, Bianchini Jr I. Cellulase and xylanase activity during the decomposition of three aquatic macrophytes in a tropical oxbow lagoon. Brazilian J Microbiol. 2011;42:909-918.

[43] Nunes MF, Cunha-Santino Md, Bianchini I, Jr. Xylanase and cellulase activities during anaerobic decomposition of three aquatic acrophytes. Brazilian J Microbiol. 2011;42:75-83.

[44] Cunha MB, Bianchini I, Jr. Cinéticas de mineralização aeróbica de celulose e lignina durante a degradação de Cabomba piauhyensis e Scirpus cubensis. Acta Limnol Bras. 1998;10:59-69.

[45] Bianchini I, Jr., Cunha-Santino MD, Romeiro F, et al. Emissions of methane and carbon dioxide during anaerobic decomposition of aquatic macrophytes from a tropical lagoon (São Paulo, Brazil). Acta Limnol Bras. 2010;22:157-164.

[46] Gramss G, Ziegenhagen D, Sorge S. Degradation of soil humic extract by wood- and soil-associated fungi, Bacteria, and commercial enzymes. Microb Ecol. 1999;37:140-151. 